
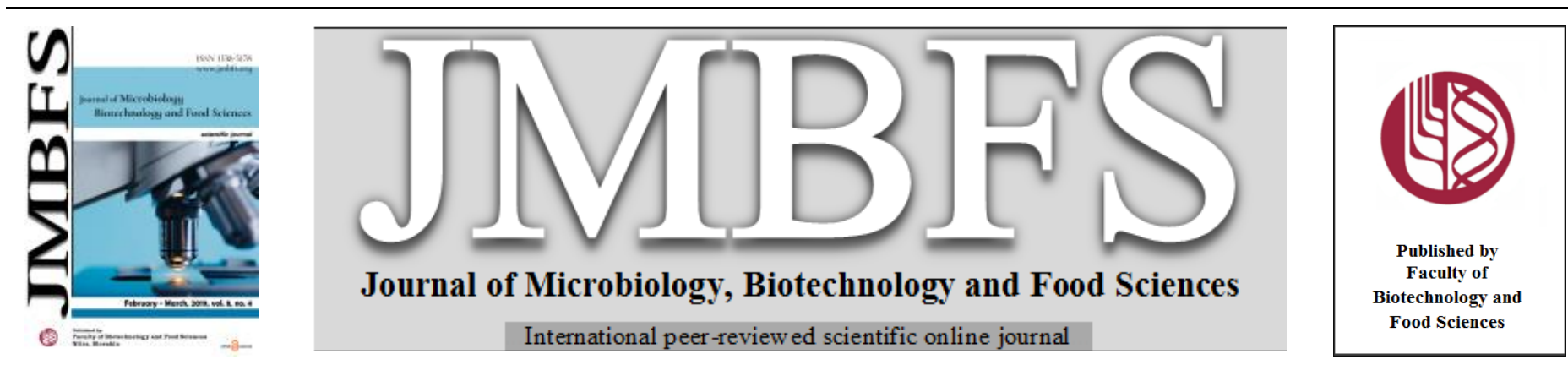

\title{
EVALUATION OF HEAVY METALS AND PESTICIDES CONTENTS IN MARKET-GARDENING PRODUCTS SOLD IN SOME PRINCIPAL MARKETS OF OUAGADOUGOU (BURKINA FASO)
}

\author{
Tarnagda Bakary ${ }^{1}$, Guira Flibert ${ }^{1}$, Sourabié Pane Bernadette ${ }^{2}$, Zongo Oumarou ${ }^{1}$, Tapsoba François ${ }^{1}$, Zongo Cheikna ${ }^{1}$, Drabo Koine \\ Maxime $^{2}$, Traoré Yves ${ }^{l}$, Savadogo Aly ${ }^{l *}$
}

Address(es): Prof. SAVADOGO Aly,

${ }^{1}$ Laboratory of Applied Biochemistry and Immunology (LaBIA), Research Center in Biological, Food and Nutritional Sciences, University Ouaga I Pr Joseph KiZerbo, 03 BP7021, Ouagadougou, Burkina Faso.

${ }^{2}$ National Laboratory of Public health, Department of Pesticides, Contaminants and Manure, Tel/Fax (226) 253731 31, 09 BP 24 Ouagadougou 09, Burkina Faso.

*Corresponding author: alysavadogo@gmail.com

doi: 10.15414/jmbfs.2019.8.4.1026-1034

\section{ARTICLE INFO}

Received 27. 5. 2018

Revised 4. 11. 2018

Accepted 7. 11. 2018

Published 1. 2. 2019

Regular article

open $\partial_{\text {ACCESS }}$

\begin{abstract}
Pesticides and heavy metals are persistent organic pollutants responsible for immune deficiency, certain types of cancer, and decreased length of pregnancy.In this study, 20 chemical pesticides and 4 heavy metals were detected from 120 samples of 4 types of vegetables and 40 samples of babenda collected from Ouagadougou principal markets. The "babenda" is a Burkinabe dish made mainly of leafy vegetables (Hibiscus sabdariffa, Amaranthus hybridus, and Cleome gynandra) coarsely chopped and millet or rice that was boiled together.A multi-residue method was developed to detect the pesticides in the samples collected by gas chromatography, with micro electron capture detector. The concentration of cadmium, lead, mercury and arsenic were obtained from the 120 vegetables samples by using an atomic absorption spectrometer. Residues of pesticides were detected in $87 \%$ of the samples, and among the positive samples, $58.40 \%$ contained concentrations higher than the limit of maximum residue (LMR). Thirteen active pesticide residues were detected in the vegetables. The contents of the majority of pesticides residues were higher than the LMR. Seven active ingredients were detected in the babenda. $50 \%$ of the samples had more than one pesticide residue. The heavy metal concentrations ranged from 0.0098 to 2.66 mg.kg ${ }^{-1}$ for $\mathrm{Hg}$; 0.01 to $1.146 \mathrm{mg} . \mathrm{kg}^{-1}$ for $\mathrm{Pb} ; 0.016$ to $1.72 \mathrm{mg} . \mathrm{kg}^{-1}$ for $\mathrm{Cd}$ and 0.012 to $1.885 \mathrm{mg} . \mathrm{kg}^{-1}$ for As. The relative abundance of heavy metals in the vegetables followed the sequence $\mathrm{Cd}\left(0.018 \mathrm{mg} \cdot \mathrm{kg}^{-1}\right)>\mathrm{Pb}\left(0.016 \mathrm{mg} \cdot \mathrm{kg}^{-1}\right)>\mathrm{As}\left(0.012 \mathrm{mg} \cdot \mathrm{kg}^{-1}\right)>\mathrm{Hg}(0.0098$ mg.kg $\left.{ }^{-1}\right)$. In addition, the concentration of heavy metals in the samples collected from the different markets exceeded the threshold according to the lawful maximum concentration (CMR) established in France. The continuous follow-up and a strict regulation of these pollutants in the vegetables particularly, are necessary.
\end{abstract}

Keywords: Heavy metals; Vegetables; Pesticides; Markets; Polluant , Ouagadougou

\section{INTRODUCTION}

Truck farming is being developed in cities in developing countries to ensure food security. It is also an income generating activity for households. In Africa, truck farming is currently part of hidden hunger solution among large cities' neighbourhoods population (Touré et al., 2015; Yao et al., 2016). Insects attacks and plants pathologies are most of the obstacles to truck farming. Marketgardeners use available chemical pesticides to limit the damage to their crops Unfortunately pesticides are used in anarchistic and abusive ways (Son $\boldsymbol{e t}$ al., 2017; Tarnagda et al., 2017). The risk of this practice is also increased by the ignorance of the market-gardeners (Diop, 2013).

Urban origin market-garden products are nutritionally rich but are not always safe. The production sites of market-garden products around urban cities are subject to contamination by residues of medicine (Koffi-Nevry et al., 2012; Touré et al., 2015). Majority of the sites of production of market-garden products are located in places polluted with domestic and industrial wastes. Some sites of gardening in the urban cities are located in or close to household refuse dump sites or industrial waste disposal sites where there is frequent incinerations of wastes (Ahouangninou et al., 2011; Kanda $\boldsymbol{e t}$ al., 2013). Pesticides are frequently used to increase vegetables production (Yao et al., 2016; Son et al., 2017; Tarnagda et al., 2017). Pesticides and heavy metals have chronic effects on human health. Among the critical points for hazard analysis of market-garden products, the site of production and the utilization of pesticides are very important. Without an adequate mechanism of control, the use of pesticides present a medical and an environmental risk (Yao et al., 2016; Tarnagda et al., 2017). The effects on the environment in general, the ground and the cultivated plants in particular, are considerable, because these husbandries are likely to involve an accumulation of heavy metals and pesticides in the plants and the surface layers of the ground, rich in organic matter (Touré et al., 2015).
The "babenda" is a Burkinabe dish made mainly of leafy vegetables (Hibiscus sabdariffa, Amaranthus hybridus, and Cleome gynandra) coarsely chopped and millet or rice that was boiled together.Vegetables play an important role in diversifying the diets of people in developing countries and are a major source of nutrients. Indeed, because of their richness in protein, fiber, minerals, vitamins, and antioxidants, vegetables help to improve the health of populations (Lock $\boldsymbol{e t}$ al., 2005). They are therefore of nutritional interest in the fight against micronutrient deficiencies (Devadas et al., 1980). The iron content of amaranth (Amaranthus cruentus) and cornet (Corchorus olitorius) is 22 to $77 \mathrm{mg} / 100 \mathrm{~g}$ dry matter (Ndlovu et al., 2008). The $\beta$-carotene content of black nightshade (Solanum scabrum) is $3943.03 \pm 0.89 \mu \mathrm{g} / 100 \mathrm{~g}$ in relation to the crude product (Soro et al., 2012).It is a sauce that is prepared in the villages during the lean season, when there was not enough millet or other grains to provide for the families until the harvest. In fact, at the base of this leaf sauce was mainly bean leaves and sorrel crushed and millet that were boiled together.This study was aimed at evaluating the contents of heavy metals and pesticides of marketgardening products (Amaranthus hybridus, Hibiscus sabdariffa, Cleome gynandra and Ipomaea batatas) and babenda sold in twenty principal markets of Ouagadougou.

\section{MATERIAL AND METHODS}

\section{Sampling and preparation of the vegetables}

A total of 120 samples of four vegetables and 40 babenda samples commonly consumed by the local population were collected. The concerned vegetables were: Amaranthus hybridus: Borom-bouli, Hibiscus sabdariffa: Bito, Cleome gynandra: Kenebdo, and pomaea batata: Nagnui-noodo Samples were taken randomly from 20 principal markets ( Zone1 yaar, Wemtenga yaar, : Zogona 
yaar, : Nabi yaar, : Benogo yaar, : Katré yaar, : Kossodo yaar, : Dassassgho yaar, : Bonsé yaar, : City Year II, : Oscar yaar, : Gounghin yaar, : Boulmiougou yaar, Tanghin yaar, : Pissy yaar, : Power station, : Larlé yaar, : Tampouy yaar, Paagala yiri and : Sankaré yaar) of Ouagadougou. The markets are codified A to T. Ouagadougou, commonly known as Ouaga, is the capital and largest city of Burkina Faso, with a population of 2.5 million in 2015. It is the The market cultural, economic and administrative center of the country.Sampling was carried out in accordance with the directive of EU 2002/63/CE (EC, 2002). A composite sample of 1-2 $\mathrm{kg}$ of each vegetable were collected and sealed in sterile polyethylene bags. Samples were codified with a single identifier and placed in a refrigerator until analysis in National Laboratory of Public Health at Ouagadougou. The samples were stored at $4{ }^{\circ} \mathrm{C}$ until the analysis. Analyses were carried out within $24 \mathrm{~h}$ according to recommendation of Islam and Shamsad (2009). The analyses was focused on edible parts.

\section{Determination of heavy metals contents in the vegetables samples}

For the analysis of heavy metals, $0.3 \mathrm{~g}$ of each freeze-dried samples were digested using $6 \mathrm{ml}$ of $\mathrm{HNO}_{3}\left(69 \%\right.$ ) and $2 \mathrm{ml}$ of $\mathrm{H}_{2} \mathrm{O}_{2} 30 \%$ (Wako Chemical Co, Japan) in a digestion system by microwaves (Berghof Speedwave, Germany). The digested samples were then transferred into a Teflon Becher, and the volume was completed to $50 \mathrm{ml}$ by Milli-Q water. The digested solution was then filtered using a syringe filter (Dismic ${ }^{\mathbb{B}}-25 \mathrm{hp}$ PTFE, size of the pores $1 / 40,45 \mathrm{~mm}$, Toyo Roshi Kaisha, Ltd, Japan, 1979) and stored in polypropylene tubes of $50 \mathrm{~m}$ (Nalgene, New York, the USA). The method of Awofolu (2005) was adopted for the acid digestion of vegetables samples. The analyses were carried out by atomic absorption with a spectrometer (Baise et Paquereau, 1997). Tab 1 shows the thresholds used to diagnose the contamination of gardens grounds and the plants.

Table 1 Thresholds used to diagnose the contamination of the plants

\begin{tabular}{|c|c|c|}
\hline ETM & Content $\left(\mathrm{mg} / \mathrm{kg}^{-1}\right)$ & References \\
\hline \multirow[t]{4}{*}{$\mathrm{Cd}$} & 0,1 & AQSIQ, (2001) \\
\hline & 0,2 & $\begin{array}{l}\text { FAO/WHO (2001); CMR (Mench \& } \\
\text { Baize, 2004) }\end{array}$ \\
\hline & 0,05 & AQSIQ, (2001) \\
\hline & 1,5 & Indian standards (Awashti, 2000) \\
\hline \multirow[t]{3}{*}{$\mathrm{Pb}$} & 0,1 & (FAO/WHO, 2011) \\
\hline & 0,2 & AQSIQ, (2001) \\
\hline & 0,3 & $\begin{array}{l}\text { CMR (Mench \& Baize, 2004); Valeur } \\
\text { maximale du règlement 1881/2006/CE } \\
\text { (Tremel- Schaub \& Feix, 2005) }\end{array}$ \\
\hline AS & 0,1 & (FAO/WHO, 2011) \\
\hline $\mathrm{Hg}$ & 0,05 & $\begin{array}{l}\text { Based on the Chinese standard (GB } \\
\text { 2762-2012) }\end{array}$ \\
\hline
\end{tabular}

\section{Pesticides contents determination}

\section{Extraction and cleaning of the samples}

The QuECHERS method was used with some modifications (Qozowicka et al., 2012). A micro-extraction of the sample finely crushed with acetonitrile was carried out in centrifuge tubes. While taking as a starting point of the literature (Anastassiades, 2005), the purification of the extracts was carried out by centrifugation with salts (sulphate of anhydrous sodium) and carbon black graphitized (GCB) to mobilize the coloured substances (chlorophyl and carotene) that are non-active by precipitation. The supernatant obtained from the frozen extract after centrifugation was recovered in a vial using a Pasteur pipette. The analysis of the extracts was carried out using a chromatograph in gas phase (Agilent Technologies) that has a micro-detector that captures electron (GC$\mu \mathrm{ECD} / \mathrm{GC}$-FPD, Hewlett Packard). A capillary chromatographic column of type $\mathrm{dB}-17 \mathrm{MS}$. It had a length of $30 \mathrm{~cm}$, an internal diameter of $250 \mu \mathrm{m}$ and a thickness of $0.25 \mu \mathrm{m}$. Nitrogen of high purity was used as the carrier gas. The injection was carried out using Split/Splitless injection technique with an injection volume of $2 \mu \mathrm{l}$. The temperatures of the apparatus were as follows:

- Room of injector programmed at $275^{\circ} \mathrm{C}$ with a pressure of $20.72 \mathrm{psi}$;

- Column $\left(75^{\circ} \mathrm{C}\right.$ during $0.5 \mathrm{mn}, 75-300^{\circ} \mathrm{C}$ with a flow of $10^{\circ} \mathrm{C} / \mathrm{mn}$ and $300^{\circ} \mathrm{C}$ during $7 \mathrm{mn})$;

- Detector $\left(325^{\circ} \mathrm{C}\right)$.

\section{Statistical analysis}

Principal component analyses (PCA), were carried out, in order to determine the correlations between the various elements.

\section{RESULTS AND DISCUSSION}

\section{Evaluation of metals traces in the market-gardening products}

The results of the levels of heavy metals in the plants are presented in Tab 2 Heavy metals found in the vegetables sold in markets of Ouagadougou town are $\mathrm{Cd}, \mathrm{Pb}, \mathrm{AS}$ and $\mathrm{Hg}$.

Table 2 Average values of heavy metals $\left(\mathrm{mg}^{-\mathrm{kg}^{-1}}\right)$ in fresh vegetables sold in various markets of Ouagadougou town.

\begin{tabular}{llllll}
\hline Heavy metals $\left(\mathrm{mg} . \mathrm{kg}^{-1}\right.$ ) & & & & \\
\hline Species & Site of study (codes of markets) & $\mathrm{Hg}$ & $\mathrm{Pb}$ & $\mathrm{Cd}$ & $\mathrm{As}$ \\
\hline Amaranthus hybridus & $\mathrm{A}$ & $3.842 \pm 0.001$ & $0.017 \pm 0.015$ & $3.939 \pm 0.04$ & $1.404 \pm 0.04$ \\
Cleome gynandra & $\mathrm{B}$ & $0.323 \pm 0.02$ & $0.129 \pm 0.06$ & $0.698 \pm 0.09$ & $0.002 \pm 0.01$ \\
Hibiscus sabdariffa & $\mathrm{C}$ & $\mathrm{ND}$ & $0.176 \pm 0.01$ & $0.734 \pm 0.06$ & $1.495 \pm 0.03$ \\
Ipomaea batatas & $\mathrm{D}$ & $\mathrm{ND}$ & $0.027 \pm 0.08$ & $0.017 \pm 0.08$ & $0.292 \pm 0.02$ \\
Cleome gynandra & $\mathrm{E}$ & $\mathrm{ND}$ & $0.012 \pm 0.02$ & $0.742 \pm 0.012$ & $1.691 \pm 0.04$ \\
Hibiscus sabdariffa & $\mathrm{F}$ & $0.256 \pm 0.00$ & $0.114 \pm 0.05$ & $2.799 \pm 0.015$ & $0.074 \pm 0.02$ \\
Amaranthus hybridus & $\mathrm{G}$ & $0.305 \pm 0.00$ & $0.119 \pm 0.012$ & $0.395 \pm 0.015$ & $0.176 \pm 0.04$ \\
Ipomaea batatas & $\mathrm{H}$ & $2.66 \pm 0.05$ & $0.013 \pm 0.01$ & $0.148 \pm 0.05$ & $\mathrm{ND}$ \\
Amaranthus hybridus & $\mathrm{I}$ & $0.103 \pm 0.001$ & $1.027 \pm 0.06$ & $0.292 \pm 0.015$ & $1.887 \pm 0.013$ \\
Hibiscus sabdariffa & $\mathrm{J}$ & $0.624 \pm 0.001$ & $1.014 \pm 0.07$ & $0.174 \pm 0.008$ & $\mathrm{ND}$ \\
Cleome gynandra & $\mathrm{K}$ & $\mathrm{ND}$ & $0.156 \pm 0.02$ & $0.252 \pm 0.013$ & $\mathrm{ND}$ \\
Ipomaea batatas & $\mathrm{L}$ & $\mathrm{ND}$ & $0.016 \pm 0.035$ & $0.119 \pm 0.018$ & $1.395 \pm 0.005$ \\
Hibiscus sabdariffa & $\mathrm{M}$ & $\mathrm{ND}$ & $0.127 \pm 0.015$ & $0.250 \pm 0.055$ & $0.001 \pm 0.053$ \\
Ipomaea batatas & $\mathrm{N}$ & $\mathrm{ND}$ & $0.155 \pm 0.00$ & $0.099 \pm 0.07$ & $\mathrm{ND}$ \\
Amaranthus hybridus & $\mathrm{O}$ & $\mathrm{ND}$ & $0.354 \pm 0.05$ & $2.714 \pm 0.045$ & $0.145 \pm 0.040$ \\
Cleome gynandra & $\mathrm{P}$ & $\mathrm{ND}$ & $0.018 \pm 0.07$ & $5.740 \pm 0.05$ & $\mathrm{ND}$ \\
Cleome gynandra & $\mathrm{Q}$ & $0.327 \pm 0.028$ & $0.043 \pm 0.083$ & $0.021 \pm 0.006$ & $0.016 \pm 0.084$ \\
Amaranthus hybridus & $\mathrm{R}$ & $0.098 \pm 0.017$ & $0.023 \pm 0.005$ & $0.276 \pm 0.055$ & $0.174 \pm 0.05$ \\
Hibiscus sabdariffa & $\mathrm{S}$ & $0.300 \pm 0.052$ & $1.145 \pm 0.002$ & $0.237 \pm 0.08$ & $0.190 \pm 0.012$ \\
Ipomaea batatas & $\mathrm{T}$ & $\mathrm{ND}$ & $0.035 \pm 0.075$ & $0.024 \pm 0.02$ & $0.026 \pm 0.09$ \\
\hline & $\mathrm{CMR}$ (WHO. 2004) & 2 & 0.1 & 0.2 & 0.01 \\
& $\mathrm{Mench}$ and Baize. 2004 & & & 2 \\
\hline
\end{tabular}


Cd is accumulated by both leaves of Hibiscus sabdariffa, and Ipomeae batatas and in Cleome gynandra (fig 2 and 5). Cd contents is low in the leaves of Ipomeae batatas sold in the market of Nabi yaar $\left(0.017 \mathrm{mg} . \mathrm{kg}^{-1}\right)$ and in the leaves of Hibiscus sabdariffa collected from the market of the City Year II (0.017 mg. $\left.\mathrm{kg}^{-1}\right)$. The $\mathrm{Cd}$ contents in the various plants largely exceed the thresholds recommended by FAO/OMS $\left(0.1 \mathrm{mg} \cdot \mathrm{kg}^{-1}\right)$ and $65 \%$ of the plants have $\mathrm{Cd}$ contents higher than standards $\left(0,2 \mathrm{mg} \cdot \mathrm{kg}^{-1}\right)$. For $\mathrm{Hg}, 50 \%$ of vegetables sold in several markets showed values higher than the thresholds values compared to the Chinese standard (Tab 2). The values obtained in the other plants are relatively high and largely above the tolerable threshold range ( 0.05 to $\left.2 \mathrm{mg} . \mathrm{kg}^{-1}\right)$. The values of $\mathrm{Pb}$ in the analysed vegetables ranged between 0.013 and $1.145 \mathrm{mg} \cdot \mathrm{kg}^{-1}$ And $55 \%$ of the samples collected from the 20 markets, largely exceeding the thresholds values indicated by FAO/OMS ( $\left.0.1 \mathrm{mg} \cdot \mathrm{kg}^{-1}\right) . \mathrm{Pb}$ and $\mathrm{Hg}$ were more accumulated in the leaves of Cleome gynandra, Hibiscus sabdariffa and Amaranthus hybridus (Fig 2 and 5).

The As were accumulated in the leaves of Amaranthus hybridus, Cleome gynandra and Hibiscus sabdariffa; and in $60 \%$ of the analyzed leaves. The amounts were relatively high in the leaves samples of Amaranthus hybridus from Bonsé yaar (1.887 mg. $\left.\mathrm{kg}^{-1}\right)$, Cleome gynandra $\left(1.691 \mathrm{mg} . \mathrm{kg}^{-1}\right)$ from the market of Benogo and in the leaves of Hibiscus sabdariffa taken from Zogona yaar (1.495 mg.kg ${ }^{-1}$ ). Thus, the analyses showed values of up to $1.887 \mathrm{mg} . \mathrm{kg}^{-1}$, which largely exceeded the tolerable threshold value $\left(0.1 \mathrm{mg} \cdot \mathrm{kg}^{-1}\right)$.

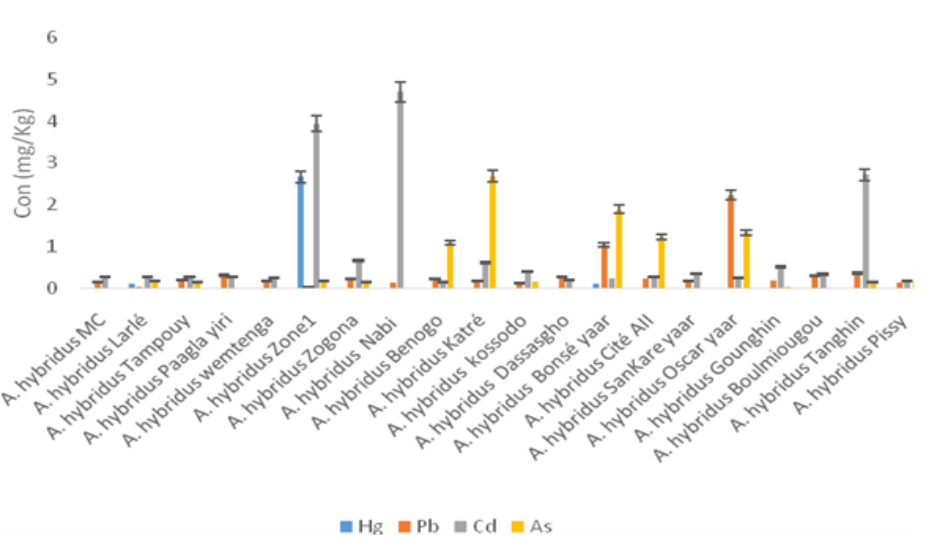

Figure 1 Heavy metal contents in Amaranthus hybridus leaves

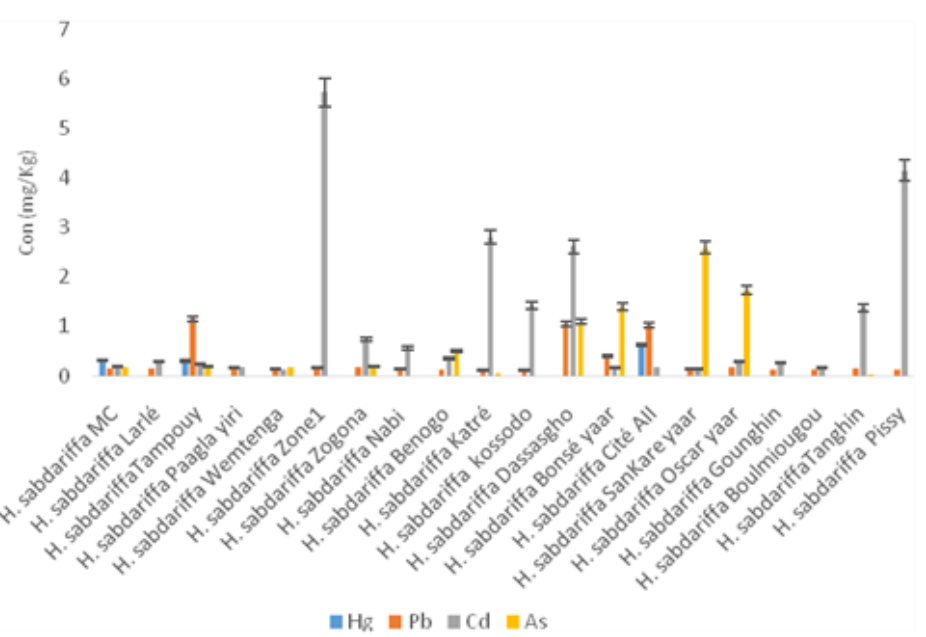

Figure 2 Heavy metal content in Hibiscus sabdariffa leaves

Various types of chemical pesticides found in the plants

The analysis of the pesticides content in plants (Tab 3) indicated that the 53,33\% of the chemical elements found in the vegetables are pesticides of the family of pyrethrinoid (permethrin, tetramethrin, cypermethrin, deltamethrin and $\lambda$ cyhalothrine); $24 \%$ of the organochlorinated compounds (lindane, alachlore, heptachlore, dieldrine); $22,67 \%$ of the organophosphorus compounds and carbamates (chlorpyrifos-methyl, parathion-ethyl, diazinon and quintozène).

Table 3 Pesticide contaminated vegetables sold in Ouagadougou

\begin{tabular}{|c|c|c|c|c|c|c|}
\hline $\begin{array}{l}\text { Culture/family/species (number of } \\
\text { sampling) }\end{array}$ & $\begin{array}{l}\text { Name of the pesticides } \\
\text { detected }\end{array}$ & $\begin{array}{l}\text { Number of } \\
\text { contaminated } \\
\text { samples }\end{array}$ & $\begin{array}{l}\text { Sample } \\
\text { exceeding } \\
\text { numbers of } \\
\text { the MRL }\end{array}$ & $\begin{array}{l}\text { Number of } \\
\text { samples } \\
\text { containing } \\
\text { multiple } \\
\text { residues of } \\
\text { pesticides for } \\
\text { each product } \\
\end{array}$ & $\begin{array}{l}\text { Range } \\
\text { pesticide/Residues } \\
\left(\mathrm{mg}^{\left.-\mathrm{kg}^{-1}\right)}\right.\end{array}$ & $\operatorname{MRL}\left(\mathrm{mg} \cdot \mathrm{kg}^{-1}\right.$ ) \\
\hline \multirow{13}{*}{ Amaranth /Amaranthus hybridus/ (30) } & Tetramethrine & 3 & & 1 & $0.097-0.365$ & 0.05 \\
\hline & $\Lambda$-cyhalothrine & 3 & 1 & 1 & $0.099-0.107$ & $0.05-0.02$ \\
\hline & Permethrine & 1 & & 1 & $0.692-1.775$ & $0.05-0.25$ \\
\hline & Cypermethrine & 1 & & 1 & $0.102-0.826$ & 0.05 \\
\hline & Deltamethrine & 3 & 2 & 1 & $0.294-0.86$ & 0.05 \\
\hline & Lindane & 1 & 1 & & $0.014-0.65$ & 0.5 \\
\hline & Quintozene & 2 & & 1 & $0.157-0.371$ & 0.007 \\
\hline & Heptachlore & 1 & 1 & & $0.016-0.025$ & 0.05 \\
\hline & Alachlore & 1 & & & $0.082-0.198$ & 0.05 \\
\hline & Dieldrine & 1 & 1 & & $0.028-0.092$ & $0.02-0.05$ \\
\hline & Diazinon & 1 & 3 & 1 & $0.037-0.089$ & $0.01-0.05$ \\
\hline & Chlorpyrifos-methyl & 4 & 2 & 1 & $0.046-0.54$ & $0.01-0.05$ \\
\hline & Parathion-ethyl & 1 & & & $0.023-0.035$ & 0.05 \\
\hline \multirow{8}{*}{ Sorrel / Hibiscus sabdariffal (30) } & Lindane & 2 & 1 & & $0.019-0.52$ & 0.5 \\
\hline & Cypermethrine & 4 & 3 & 1 & $0.282-0.813$ & 0.05 \\
\hline & Permethrine & 1 & & 1 & $0.689-0.853$ & $0.05-0.25$ \\
\hline & Alachlore & 1 & 1 & & $0.016-0.085$ & 0.05 \\
\hline & Dieldrine & 1 & & & $0.024-0.047$ & $0.02-0.05$ \\
\hline & Deltamethrine & 3 & 1 & 1 & $0.145-0.324$ & 0.05 \\
\hline & $\Lambda$-cyhalothrine & 3 & 4 & 1 & $0.018-0.059$ & $0.05-0.02$ \\
\hline & Diazinon & 1 & 2 & 1 & $0.036-0.042$ & $0.01-0.05$ \\
\hline
\end{tabular}




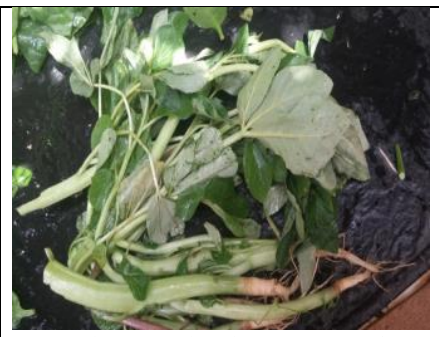

Bastard mustard /Cleome gynandra/ (30)

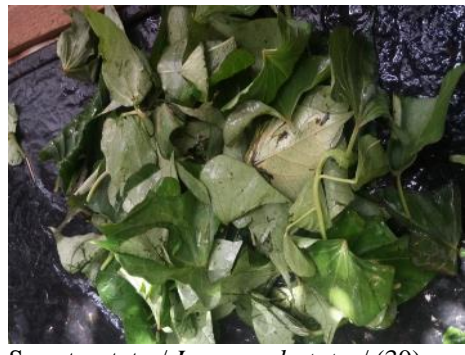

Sweet potato / Ipomaea batatas/ (30)

Total $=120$

MRL-Maximum Residue Level

The principal component analysis revealed the correlation between pesticides contents and plant species, between heavy metal contents and plants species.

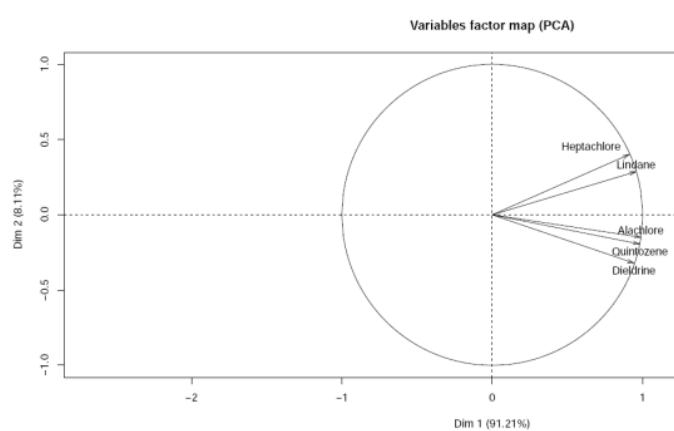

Figure 3 Principal component analysis of organochlorinated compounds and carbamates in the studied vegetable species - a: Organochlorinate and carbamate

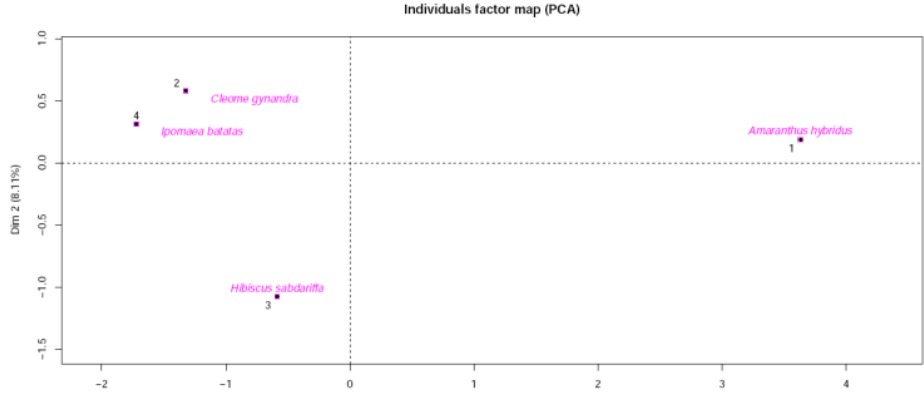

Figure 3 Principal component analysis of organochlorinated compounds and carbamates in the studied vegetable species $-b$ : Vegetable species variables factor map (PCA)

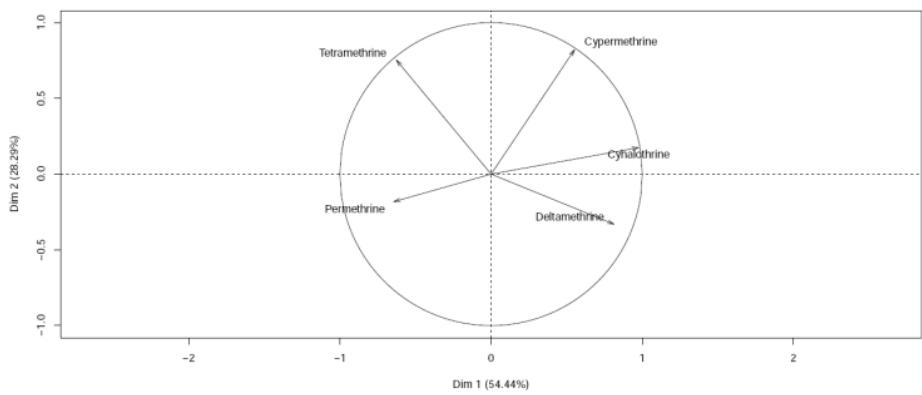

Figure 4 Principal Component Analysis of Pyrethrinoid of synthesis in the vegetables leaves - a: Pyrethrinoid synthesis in the vegetables

\begin{tabular}{|c|c|c|c|}
\hline 1 & 1 & $0.014-0.035$ & $0.01-0.05$ \\
\hline & & $0.021-0.043$ & 0.05 \\
\hline 2 & 1 & $0.069-0.178$ & $0.02-0.05$ \\
\hline 1 & 1 & $0.169-0.355$ & $0.05-0.25$ \\
\hline 1 & 1 & $0.164-0.891$ & 0.05 \\
\hline 1 & & $0.016-0.083$ & 0.05 \\
\hline 3 & & $0.096-0.132$ & 0.05 \\
\hline 4 & 1 & $0.059-0.288$ & 0.05 \\
\hline 1 & 1 & $0.169-0.326$ & $0.05-0.25$ \\
\hline 2 & & $0.178-0.574$ & $0.02-0.05$ \\
\hline 1 & 1 & $0.012-0.828$ & $0.02-0.05$ \\
\hline 4 & 1 & $0.059-0.158$ & 0.05 \\
\hline 3 & 1 & $0.155-0.925$ & 0.05 \\
\hline 47 & 22 & & \\
\hline
\end{tabular}

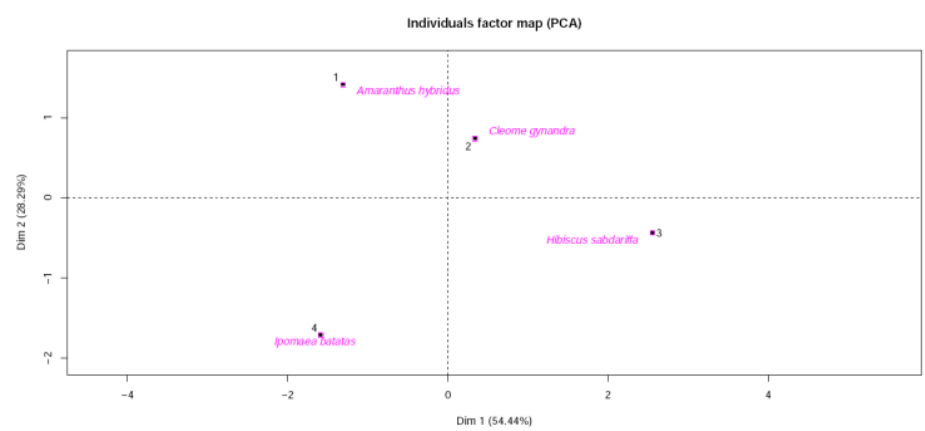

Figure 4 Principal Component Analysis of Pyrethrinoid of synthesis in the vegetables leaves $-b$ : Vegetables species

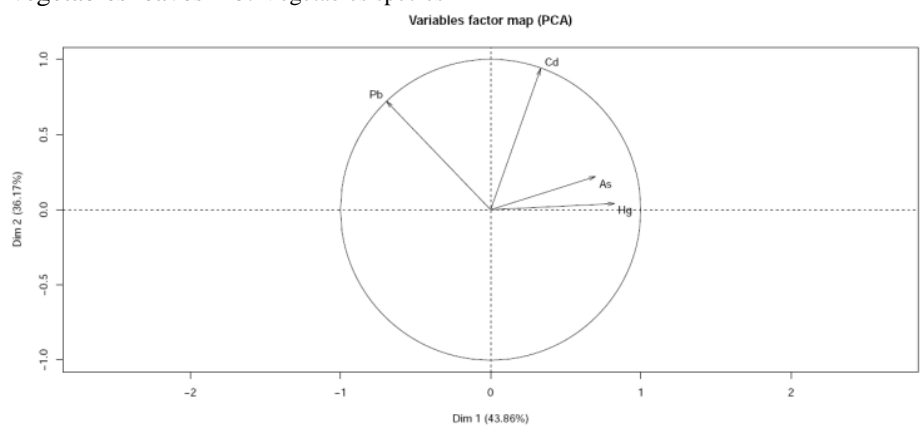

Figure 5 Principal component analysis of heavy metals in vegetables - a: Heavy metals analyses in vegetables leaves

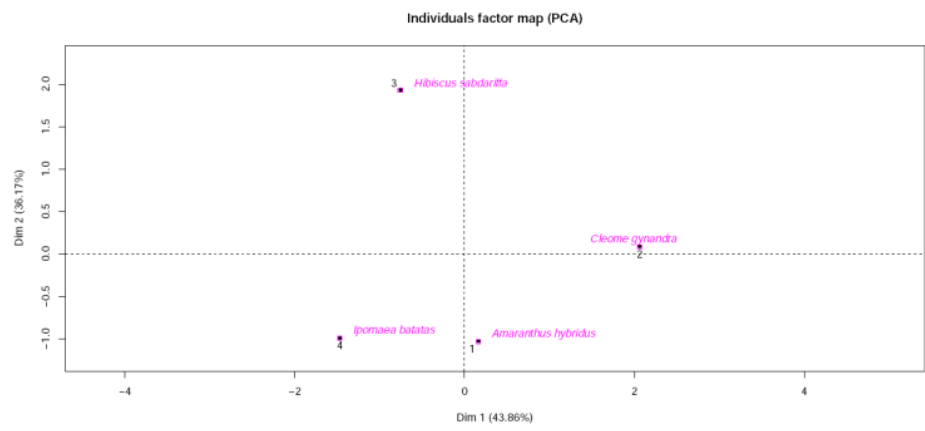

Figure 5 Principal component analysis of heavy metals in vegetables $-\mathrm{b}$ Vegetables species 


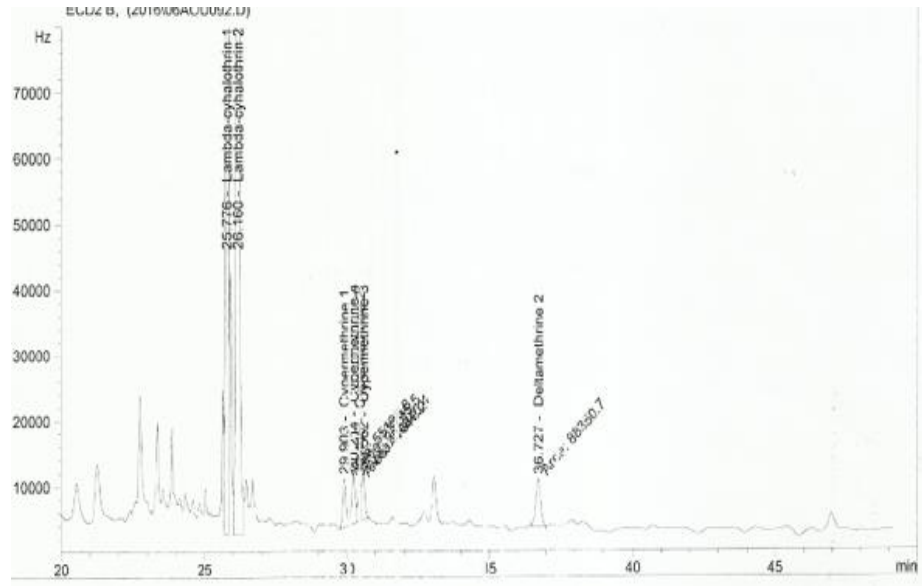

Figure 6 Chromatogram of the vegetable leaves samples containing of the residues of pesticides - a: Chromatogram of a sample of Amaranthus hybridus satisfying with pyrethrinoid with synthesis.

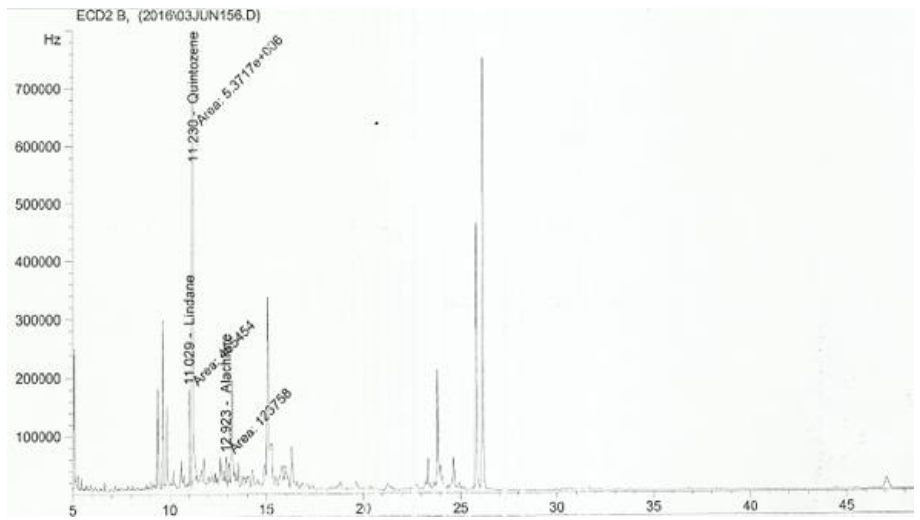

Figure 6 Chromatogram of the vegetable leaves samples containing of the residues of pesticides. - b: Chromatogram of a sample of Hibiscus sabdariffa containing the organochlorinated ones and carbamates.

\section{Residues of pesticides in the babenda, local sauce.}

In general, there was a decrease in the level of residues but it varied greatly, depending on:

(i) washing, it depends on the nature of the molecule and its formulation, the plant structure and washing methods; it only concerns contact products;

(ii)

the degree of heating (cooking or bleaching), it is also effective and can supplement for the drops due to previous treatments.

The moist heat is a significant factor. Tetramethrin was detected in the samples with contents ranging from 0.0024 to $0.0085 \mathrm{mg} . \mathrm{kg}^{-1}$, respectively. Lambdacyhalothrin concentrations ranged from 0.0049 to $0.0057 \mathrm{mg} . \mathrm{kg}^{-1}$ in samples d and $\mathrm{b}$, unlike cypermethrin, samples $\mathrm{e}-\mathrm{b}$ recorded pesticide residue levels of 0.0072 to $0.0085 \mathrm{mg} . \mathrm{kg}^{-1}$. Samples a - d recorded deltamethrin levels of 0.0043 to $0.0072 \mathrm{mg} \cdot \mathrm{kg}^{-1}$. An $80 \%$ reduction of lindane in the babenda, with a value of
0.0075 to $0.0081 \mathrm{mg} \cdot \mathrm{kg}^{-1}$ in samples $\mathrm{b}-\mathrm{c}$, while heptachlor recorded values of 0.0099 to 0.0012 mg.kg ${ }^{-1}$ in level 1 sample a- d . $92.5 \%$ tetramethrin, $15 \%$ lamabda-cyhalothrin, $87.5 \%$ cypermethrin and $60 \%$ deltamethrin were the percentages of synthetic pyrethroids removed during cooking. Compared with organochlorine insecticides, lindane had $95 \%$ and $52 \%$ heptachlor removal.

About $75.65 \%$ of the analysed plants had heavy metal contents which exceeded the threshold fixed at $0.2 ; 0.3$ and $0.1 \mathrm{mg}^{\mathrm{kg}}{ }^{-1}$, respectively for $\mathrm{Cd}, \mathrm{Pb}$ and $\mathrm{As}$ (FAO/WHO, 2001). Vegetables sold in several markets show $\mathrm{Hg}$ content below the thresholds values (Table 2$)$. The Cd contents obtained $\left(0.017\right.$ to $3.939 \mathrm{mg} . \mathrm{kg}^{-1}$ was higher than the contents obtained with the crop plants on the metallurgical grounds of Noyelles Godault and Auby in France, which reached up to $1.5 \mathrm{mg} . \mathrm{kg}$ -1 (Douay and Sterckeman, 2002; Touré et al., 2015). But a study carried out on the sites of Cocody and Maccory in Côte d'Ivoire (Gupta et al., 2008) reported Cd contents in plants lower than those of this study ( 0.12 to $0.41 \mathrm{mg} . \mathrm{kg}$ 1 ).

In the leaves of Amaranthus hybridus and Hibiscus sabdariffa collected from the markets, $\mathrm{Hg}$ was detected $(1,6,7,9,10,18,19)$, whereas in the samples of Ipomoea batatas and of Cleome gynandra, $\mathrm{Hg}$ was detected only in samples from certain markets with average values of concentration varying from 0.098 to $3.842 \mathrm{mg} . \mathrm{kg}$ ${ }^{-1}$; lower than those reported from India (Gupta et al., 2008), (2.682 to 3.947 mg.kg ${ }^{-1}$ ) and then Cameroon (Noubissié, 2015). Among the four types of vegetables examined, Cleome gynandra and Amaranthus hybridus recorded the highest level of Cd concentration which were $5.74 \mathrm{mg} . \mathrm{kg}^{-1}$ and $3.842 \mathrm{mg} \cdot \mathrm{kg}^{-1}$, respectively. Hibiscus sabdariffa recorded the highest level of $\mathrm{Pb}$ concentration which was 1.145 mg.kg ${ }^{-1}$ and Hibiscus sabdariffa recorded the highest concentration of As which was $1.691 \mathrm{mg} \cdot \mathrm{kg}^{-1}$ The average contents of the heavy metals detected in Hibiscus sabdariffa, Amaranthus hybridus, Hibiscus sabdariffa and Amaranthus hybridus were in the order: $\mathrm{Cd}>\mathrm{Pb}>\mathrm{As}>\mathrm{Hg}$. Cleome gynandra and Ipomoea batatas had high holding capacity for $\mathrm{Cd}, \mathrm{Pb}, \mathrm{As}$ and $\mathrm{Hg}$, respectively.

$\mathrm{Hg}$ acceptable limit value is $2 \mathrm{mg} . \mathrm{kg}^{-1}$, the results obtained show a high level when compared to the standards (Amaranthus hybridus 2.665 mg.kg ${ }^{-1}$ Ipomaea batatas $3.842 \mathrm{mg} \cdot \mathrm{kg}^{-1}$ ).

The result is similar to those obtained in Cameroon on plants samples (Amaranthus hybridus and Hibiscus sabdariffa) (Noubissié, 2015), 2.682 to $3.947 \mathrm{mg} \cdot \mathrm{kg}^{-1}$.

The normal acceptable values of $\mathrm{Pb}$ according to the FAO/WHO (2001) is 0.3 mg. $\mathrm{kg}^{-1}$. The average values of $\mathrm{Pb}$ found $(0.3535,0.445,0.548,1.145$ and 2.223 mg.kg ${ }^{-1}$ ) were higher than the standard set by the FAO/WHO (2011) which is only 0.1 mg.kg ${ }^{-1}$; but similar to those reported by Mpundu et al. (2013) (0.72 and $1.72 \mathrm{mg} \cdot \mathrm{kg}^{-1}$ ). Whereas the toxic nature of $\mathrm{Pb}$ has been known for a long time, as well as the dangers related to the contamination of food by this metal (Mourato et al., 2015). But these values are lower than those reported in DR Congo with values of $3.67,4.089 ; 5.21,7.547$ and $10.25 \mathrm{mg} . \mathrm{kg}^{-1}$. The results of this study corroborate with those obtained by Noubissié (2015) who reported values of $0.134,0.283,2.697$ and $3.503 \mathrm{mg} . \mathrm{kg}^{-1}$. The high $\mathrm{Pb}$ values recorded in certain vegetables are probably as a result of pollutants in the water of irrigation, agricultural grounds or road traffic (Qui et al., 2000).

Wong et al. (1996) reported that the Chinese cabbage more easily collects $\mathrm{Pb}$ compared to other heavy metals such as $\mathrm{Cd}, \mathrm{Cu}, \mathrm{Ni}$ and $\mathrm{Zn}$. The $\mathrm{Pb}$ rate in this study is higher in the leaves of Hibiscus sabdariffa $\left(1.145 \mathrm{mg} . \mathrm{kg}^{-1}\right)$ and weaker in the sheet of Ipomaea batatas $\left(0.013 \mathrm{mg} . \mathrm{kg}^{-1}\right)$. The $\mathrm{Pb}$ rates reported in this study are higher than that reported in lettuce leaves $\left(0.01 \mathrm{mg} . \mathrm{kg}^{-1}\right)$ by Adu $\boldsymbol{e t}$ al. (2012).

Table 4 Total concentrations of pesticides $\left(\mathrm{mg}^{\mathrm{kg}}{ }^{-1}\right)$ in the "babenda" leaf sauce collected from the markets of the city of Ouagadougou.

\begin{tabular}{|c|c|c|c|c|c|c|c|c|}
\hline \multirow[b]{2}{*}{ Market } & \multirow[b]{2}{*}{ Babenda } & \multicolumn{6}{|c|}{ Pesticides detected in babenda $\left(\mathrm{mg} \cdot \mathrm{kg}^{-1}\right)$} & \multirow[b]{2}{*}{ Deltaméthrine } \\
\hline & & Tetraméthrine & Heptachlore & Lindane & $\lambda$-Cyhalothrine & Cyperméthrine & Perméthrine & \\
\hline \multirow{6}{*}{ Market $1(08)$} & a & $<\mathrm{LQ}$ & $<\mathrm{LQ}$ & $<\mathrm{LQ}$ & 0,0020 & $<\mathrm{LQ}$ & $<\mathrm{LQ}$ & $<\mathrm{LQ}$ \\
\hline & $\mathrm{b}$ & $<\mathrm{LQ}$ & 0,0010 & 0,0075 & 0,0042 & $<\mathrm{LQ}$ & $<\mathrm{LQ}$ & $<\mathrm{LQ}$ \\
\hline & c & $<\mathrm{LQ}$ & $<\mathrm{LQ}$ & 0,0081 & 0,0093 & $<\mathrm{LQ}$ & $<\mathrm{LQ}$ & $<\mathrm{LQ}$ \\
\hline & d & $<\mathrm{LQ}$ & 0,0012 & $<\mathrm{LQ}$ & 0,0051 & 0,0056 & 0,006 & 0,0059 \\
\hline & e & $<\mathrm{LQ}$ & $<\mathrm{LQ}$ & $<\mathrm{LQ}$ & 0,0310 & $<\mathrm{LQ}$ & $<\mathrm{LQ}$ & $<\mathrm{LQ}$ \\
\hline & f & $<\mathrm{LQ}$ & $<\mathrm{LQ}$ & $<\mathrm{LQ}$ & $<\mathrm{LQ}$ & $<\mathrm{LQ}$ & $<\mathrm{LQ}$ & 0,0019 \\
\hline \multirow{6}{*}{ Market 2 (08) } & $\mathrm{a}$ & $<\mathrm{LQ}$ & 0,0012 & $<\mathrm{LQ}$ & 0,0011 & $<\mathrm{LQ}$ & $<\mathrm{LQ}$ & $<\mathrm{LQ}$ \\
\hline & $\mathrm{b}$ & $<\mathrm{LQ}$ & $<\mathrm{LQ}$ & $<\mathrm{LQ}$ & 0,0057 & $<\mathrm{LQ}$ & $<\mathrm{LQ}$ & $<\mathrm{LQ}$ \\
\hline & $\mathrm{c}$ & $<\mathrm{LQ}$ & 0,0013 & $<\mathrm{LQ}$ & $<\mathrm{LQ}$ & $<\mathrm{LQ}$ & $<\mathrm{LQ}$ & $<\mathrm{LQ}$ \\
\hline & d & $<\mathrm{LQ}$ & 0,0097 & $<\mathrm{LQ}$ & 0,0015 & $<\mathrm{LQ}$ & $<\mathrm{LQ}$ & 0,0076 \\
\hline & $\mathrm{e}$ & $<\mathrm{LQ}$ & $<\mathrm{LQ}$ & $<\mathrm{LQ}$ & 0,0030 & $<\mathrm{LQ}$ & $<\mathrm{LQ}$ & 0,0072 \\
\hline & $\mathrm{f}$ & $<\mathrm{LQ}$ & $<\mathrm{LQ}$ & $<\mathrm{LQ}$ & 0,007 & $<\mathrm{LQ}$ & $<\mathrm{LQ}$ & $<\mathrm{LQ}$ \\
\hline \multirow{5}{*}{ Market $3(08)$} & $\mathrm{a}$ & $<\mathrm{LQ}$ & 0,0010 & $<\mathrm{LQ}$ & $<\mathrm{LQ}$ & 0,0085 & 0,0086 & $<\mathrm{LQ}$ \\
\hline & $\mathrm{b}$ & 0,0081 & 0,0011 & $<\mathrm{LQ}$ & 0,0049 & $<\mathrm{LQ}$ & $<\mathrm{LQ}$ & 0,00793 \\
\hline & $\mathrm{c}$ & $<\mathrm{LQ}$ & 0,0010 & $<\mathrm{LQ}$ & $<\mathrm{LQ}$ & $<\mathrm{LQ}$ & $<\mathrm{LQ}$ & $<\mathrm{LQ}$ \\
\hline & $\mathrm{d}$ & $<\mathrm{LQ}$ & 0,0017 & $<\mathrm{LQ}$ & 0,0049 & $<\mathrm{LQ}$ & $<\mathrm{LQ}$ & 0,0051 \\
\hline & $\mathrm{e}$ & $<\mathrm{LQ}$ & $<\mathrm{LQ}$ & $<\mathrm{LQ}$ & $<\mathrm{LQ}$ & $<\mathrm{LQ}$ & $<\mathrm{LQ}$ & 0,0061 \\
\hline
\end{tabular}




\begin{tabular}{|c|c|c|c|c|c|c|c|c|}
\hline & $\mathrm{f}$ & $<\mathrm{LQ}$ & $<\mathrm{LQ}$ & $<\mathrm{LQ}$ & $<\mathrm{LQ}$ & $<\mathrm{LQ}$ & $<\mathrm{LQ}$ & 0,0058 \\
\hline \multirow{6}{*}{ Market 4 (08) } & $\mathrm{a}$ & $<\mathrm{LQ}$ & 0,0099 & $<\mathrm{LQ}$ & 0,0069 & $<\mathrm{LQ}$ & $<\mathrm{LQ}$ & 0,0046 \\
\hline & $\mathrm{b}$ & $<\mathrm{LQ}$ & $<\mathrm{LQ}$ & $<\mathrm{LQ}$ & 0,0035 & $<\mathrm{LQ}$ & $<\mathrm{LQ}$ & 0,0059 \\
\hline & $\mathrm{c}$ & $<\mathrm{LQ}$ & $<\mathrm{LQ}$ & $<\mathrm{LQ}$ & 0,0054 & $<\mathrm{LQ}$ & $<\mathrm{LQ}$ & 0,0099 \\
\hline & d & $<\mathrm{LQ}$ & $<\mathrm{LQ}$ & $<\mathrm{LQ}$ & 0,0083 & $<\mathrm{LQ}$ & $<\mathrm{LQ}$ & 0,0068 \\
\hline & e & $<\mathrm{LQ}$ & 0,0013 & $<\mathrm{LQ}$ & 0,0041 & $<\mathrm{LQ}$ & $<\mathrm{LQ}$ & $<\mathrm{LQ}$ \\
\hline & $\mathrm{f}$ & $<\mathrm{LQ}$ & 0,0016 & $<\mathrm{LQ}$ & 0,0052 & $<\mathrm{LQ}$ & $<\mathrm{LQ}$ & $<\mathrm{LQ}$ \\
\hline \multirow{6}{*}{ Market 5 (08) } & $\mathrm{a}$ & 0,0085 & 0,006 & $<\mathrm{LQ}$ & 0,0057 & 0,0038 & 0,001 & 0,0043 \\
\hline & b & 0,0024 & 0,0016 & $<\mathrm{LQ}$ & 0,0017 & $<\mathrm{LQ}$ & $<\mathrm{LQ}$ & $<\mathrm{LQ}$ \\
\hline & $\mathrm{c}$ & $<\mathrm{LQ}$ & 0,005 & $<\mathrm{LQ}$ & 0,0071 & $<\mathrm{LQ}$ & $<\mathrm{LQ}$ & 0,0052 \\
\hline & d & $<\mathrm{LQ}$ & $<\mathrm{LQ}$ & $<\mathrm{LQ}$ & 0,0026 & $<\mathrm{LQ}$ & $<\mathrm{LQ}$ & 0,0042 \\
\hline & e & $<\mathrm{LQ}$ & $<\mathrm{LQ}$ & $<\mathrm{LQ}$ & 0,0053 & 0,0072 & 0,0072 & $<\mathrm{LQ}$ \\
\hline & $\mathrm{f}$ & $<\mathrm{LQ}$ & $<\mathrm{LQ}$ & $<\mathrm{LQ}$ & 0,00154 & 0,0011 & 0,001 & $<\mathrm{LQ}$ \\
\hline
\end{tabular}

a,b,c: Code samples of babenda; LO: Quantitation Limit

\section{Heavy metals}

The acceptable value of Cadmium (Cd), defined by WHO (2004) is $0.2 \mathrm{mg} \cdot \mathrm{kg}^{-1}$ The values obtained in this study $(5.74,4.702,3.9395,2.799,1.425$ and 0.742 mg.kg ${ }^{-1}$, respectively) showed higher contents than the standards of WHO (2004). Also, the results obtained in this study were higher than those reported by Kalonda et al. (2015) in DR Congo with values of 7.717, 1.981, 1.621, 1.245 and $0.782 \mathrm{mg} . \mathrm{kg}^{-1}$. Mpundu et al. (2013) reported Cd contents of 1.2 and 1.49 mg.kg ${ }^{-1}$ in the vegetables sold in the markets of mining zones of Lubumbashi.

The results obtained reveal that $\mathrm{Cd}$ concentration in the leaves was higher when compared to those reported by Rehman et al. (2016) in the five areas of Pakistan which varied from 0.2 to $1.6 \mathrm{mg} . \mathrm{kg}^{-1}$. Cd concentration for all vegetables, except Hibiscus sabdariffa, Cleome gynandra and Ipomaea batatas were respectively $0.174 \pm 0.008$ mg.kg ${ }^{-1} ; 0.021 \pm 0.006$ and $0.024 \pm 0.02$ mg.kg ${ }^{-1}$, and exceeded the limits ( 0.1 to $\left.0.2 \mathrm{mg} \mathrm{kg}^{-1}\right)$ established by SEPA (2005). Similar to the studies by shaheen et al. (2016); islam et al. (2015); rahman et al. (2013); ahmad and goni, 2010 was reported mean cd concentration of $0.013-0.056$ mg.kg $-1 ; 0.009$ -7.9 mg.kg -1 respectively and $0.01-0,2$ mg.kg -1 and 0.6 mg.kg -1 . Al-Rmalli et al. (2012) declared levels of $\mathrm{Cd}$ in not-light vegetables $(0.008 \pm 0.0008 \mathrm{mg} . \mathrm{kg}$ $\left.{ }^{1}\right)$ and in some fruits $\left(0.002 \pm 0.001 \mathrm{mg} \cdot \mathrm{kg}^{-1}\right)$. These metals were in fossil fuels, oils and lubricants, and the smoke of engines of vehicles (Li et al., 2001; Imperato et al., 2003; Dao et al., 2010 ).

For Arsenic (As), the acceptable value is limited to $0.01 \mathrm{mg} \cdot \mathrm{kg}^{-1}$ (WHO, 2004) the results obtained show that for some samples, the values were higher $(3.372$, $2.928,1.887$ and $\left.0.0106 \mathrm{mg} \cdot \mathrm{kg}^{-1}\right)$. These results are similar to those obtained by Alina et al. (2012) who reported values in As as 6.57, 2.13, 1.36 and $0.59 \mathrm{mg} . \mathrm{kg}$ ${ }^{1}$ in the samples of spinach sheet, Amaranthus hybridus and Hibiscus sabdariffa, respectively. Ubalua et al. (2007) reported some values of As $(0.01,0.02$ and 0.2 mg.kg $\left.{ }^{-1}\right)$ lower than that found in this study. These differences in contents could be due to the different farming techniques and differences in the level of contamination of the ground, the atmosphere and the water of each site where samples were collected from (Adu et al., 2014).

\section{Pesticides}

Thirteen active compounds were detected in the vegetable-leaves studied such as: the pyrethrinoid compounds (tetramethrine, permethrine, $\lambda$-cyalothrine, cypermethrine and deltamethrine), organophosphorus compound and nitrogenized compounds (diazinon, chlorpyrifos-methyl and parathion- ethyl), organochlorinated compounds (lindane, heptachlore, alachlore and dieldrine) and the carbamates (quintozene) (Fig 3 and 4).

These results are similar to those obtained by Farag $\boldsymbol{e t}$ al. (2011) who detected 16 residues of pesticides (chlorpyrifos, diazinon, malathion, profenofos, sulphur, chlorpyriphos-methyl, carbendazime, cypermethrine, ethion, propargite, perméthrine, $\lambda$-cyhalothrine, methomyl, phenpropathrin, quinalphos and pirimiphosméthyl) in the vegetables sold in the Egyptian market.

In general, the residual rates of pesticides of the 20 studied markets were either identical, below or above the hot lines of the LMR (Tab 3) authorized by FAO/WHO (2010) and the EU (2008). This may be as a result of inappropriate or abusive use of pesticides and lack of environmental education for farmers (Assogba et al., 2007). The organophosphorus pesticides were detected in almost all the vegetables analyzed with contents ranging from 0.029 to $0.089 \mathrm{mg} \cdot \mathrm{kg}^{-1}$ for the diazinon; chlorpyriphos-methyl with $0.039 \mathrm{mg} \cdot \mathrm{kg}^{-1}$ and 0.023 to $0.054 \mathrm{mg} . \mathrm{kg}$ ${ }^{-1}$ for the parathion-ethyl); often higher than the standard (EU, 2008) $(0.02 \mathrm{mg} . \mathrm{kg}$ $\left.{ }^{-1}\right)$. Similar studies carried out by Ngom et al. (2013) on the evaluation of pesticides residues in the horticultural products consumed in Senegal detected residues of pesticides that are from organophosphorus compounds, in onion leaves with 0.017 and $0.014 \mathrm{mg} \cdot \mathrm{kg}^{-1}$ in headed cabbage. The results of this study are largely higher than those recorded by Farag $\boldsymbol{e t}$ al. (2011) who detected diazinon in the vegetables sold in the Egyptian markets, with values of 0.01 and $0.016 \mathrm{mg} . \mathrm{kg}^{-1}$ for chlorpyriphos-methyl. But these results are lower than those obtained by Touré $\boldsymbol{e t}$ al. (2015) who reported contents of chlorpyriphos-methyl as 0.338 mg.kg ${ }^{-1}$ in Amaranthus hybridus during the analysis of pesticides residues in the market-gardening products collected from the dam Loumbila of Burkina Faso

For lindane, the collection of different vegetables in the markets of Ouagadougou showed contents that largely exceeded the LMR $\left(0.5\right.$ mg.kg $\left.{ }^{-1}\right)$ with respective average concentrations of 0.52 and $0.65 \mathrm{mg} . \mathrm{kg}^{-1}$ (Tab 3). On the other hand, for the heptachlore, the highest content was recorded, varying from 0.016 to 0.025 $\mathrm{mg} . \mathrm{kg}^{-1}$, and alachlore recorded contents such as $0.085,0.092$ and $0.198 \mathrm{mg} . \mathrm{kg}^{-1}$ in the samples of vegetables analyzed (Tab 3). The values of dieldrine recorded in the vegetables were $0.92,1.023$ and $1.47 \mathrm{mg} . \mathrm{kg}^{-1}$. These results are similar to those obtained by Kanda et al. (2009). Congo (2013) reported residues of organochlorinated pesticides with variable concentrations $(0.586,1.095$ and $3.913 \mathrm{mg} \cdot \mathrm{kg}^{-1}$ ) in vegetables samples cultivated in the market-gardening perimeter of Lomé, Togo and Burkina Faso. These were collected from various markets of the countries.Compared to those obtained by Bempah et al. (2011), $\left(0.04\right.$ and $\left.0.1 \mathrm{mg} \cdot \mathrm{kg}^{-1}\right)$ in the samples of vegetables and spices collected from supermarkets and markets of Kumasi (Ghana). For the alachlore, the contents obtained in this study are higher $\left(0.714 \mathrm{mg} \cdot \mathrm{kg}^{-1}\right)$ than those reported by Sène (2008) in lettuce and cabbage collected from Niayes Power Stations of Thiès with concentrations varying between 0.001 and $0.026 \mathrm{mg} . \mathrm{kg}^{-1}$.

The contamination of leaves by pyrethrinoid compound is also high even if its remanence is weaker compared to other active matters. The contents of these five active matters exceeded the LMR for the analyzed plants $\left(0.096 \mathrm{mg} \cdot \mathrm{kg}^{-1}\right.$ for tetramethrine, $0.018 \mathrm{mg} \cdot \mathrm{kg}^{-1}$ for $\lambda$-cyalothrine, $0.0826 \mathrm{mg} . \mathrm{kg}^{-1}$ for cypermithrine, $0.169 \mathrm{mg} \cdot \mathrm{kg}^{-1}$ forpermethrine and $0.059 \mathrm{mg} \cdot \mathrm{kg}^{-1}$ for deltamethrine) (Tab 3). The results of pyrethrinoid obtained in this study are largely higher than those obtained by Touré $\boldsymbol{e t}$ al. (2015) who, in a study on the evaluation of the metaltraces, pesticides and plasticizers in the market-gardening products (gombo, corète pot, spinach and aubergine) in the valley of the nieki, south-east of the Ivory Coast, obtained $0.007 \mathrm{mg} . \mathrm{kg}^{-1}$ of $\lambda$-cyalothrine in spinach against 0.022 mg.kg ${ }^{-1}$ of $\lambda$-cyalothrine in pot corete. Deltamethrine gave a concentration of $0.053 \mathrm{mg} \cdot \mathrm{kg}^{-1}$ for the pot corete and $0.009 \mathrm{mg} \cdot \mathrm{kg}^{-1}$ for spinach. The contents of pesticides residues obtained from the analyses in this study remained higher than those recommended by Codex alimentaruis (2010) and the $\mathbf{E U ~ ( 2 0 0 8 )}$ in the plants. The total concentrations of the pyrethrinoid residues recorded are higher than those obtained by Coly (2000). The total concentrations of pyrethrinoid residues are also higher than those obtained by Ngom $\boldsymbol{e t}$ al. (2013); with contents ranging between 0.006 and $0.01 \mathrm{mg} \cdot \mathrm{kg}^{-1}$ for the deltamethrine in samples collected from the markets of Beavers and Large-Dakar. The results of this study are also higher than those published by Diop (2013) whose contents of deltamethrine lie between $0.087 \mathrm{mg} . \mathrm{kg}^{-1}$ in cabbage and $0.002,0.009$ and 0.018 mg.kg ${ }^{-1}$ for salad and $\lambda$-cyhalothrine with contents of $0.316 \mathrm{mg} . \mathrm{kg}^{-1}$ in cabbage and $0.012,0.061$ and $0.222 \mathrm{mg} . \mathrm{kg}^{-1}$ for salad; during a study that was related to the diagnosis of the practices of use and quantification of the pesticides in the zone of Niayes of Dakar (Senegal). For $\lambda$ - cyalothrine, the average contents observed are higher $\left(2.035 ; 3.153\right.$ and 4.475 mg.kg $\left.{ }^{-1}\right)$ than those reported as standards in the United States and in Western Europe which lay between 0.01 and 0.67 mg.kg ${ }^{-1}$ (Codex Alimentaruis, 2010)

In Poland, Qozowicka et al. (2012) also reported that chlorpyrifos was $27.4 \%$ (100) in their analyzed samples. The range of chlorpyrifos-methyl in Amaranthus hybridus ( 0.046 to $0.54 \mathrm{mg} . \mathrm{kg}^{-1}$ ) obtained in this study are similar to those reported by Chowdhury et al. (2013), who detected chlorpyrifos-methyl in majority of the vegetable samples $\left(0.04\right.$ to $\left.0.70 \mathrm{mg} \cdot \mathrm{kg}^{-1}\right)$. The concentration of chlorpyrifos in the leaves of Hibiscus sabdariffa varied from 0.014 to 0.035 mg.kg ${ }^{-1}$, in five samples having the highest concentration less than the LMR $\left(0.50 \mathrm{mg} . \mathrm{kg}^{-1}\right)(\mathrm{Tab} 3)$. In addition, the studies carried out in the United States, China and Venezuela reported alarming results. These authors reported high concentrations of chlorpyrifos in tomatoes samples collected from Florida (0.07 mg.kg ${ }^{-1}$ (Stevens and Kilmer, 2009), from Xiamen, China (3.8 mg.kg ${ }^{-1}$ ) (Chen

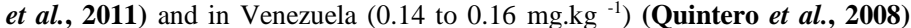
However, the results of this study recorded lower concentration in the leaves of Hibiscus sabdariffa (0.014 to $0.035 \mathrm{mg} . \mathrm{kg}^{-1}$ ) when compared to those found in tomatoes samples of Hyderabad, Pakistan (average concentration was $0.22 \mathrm{mg} . \mathrm{kg}$ $\left.{ }^{-1}\right)$ (Latif et al., 2011) and India (0.158 mg.kg $\left.{ }^{-1}\right)$ (Sinha et al., 2012). Chlorpyrifos contents in the analyzed plants also recorded lower concentrations 
than those reported by Chowdhury et al. (2013) who reported contents of chlorpyrifos in cauliflower ranging from 0.062 to $0.080 \mathrm{mg} \cdot \mathrm{kg}^{-1}$. These samples are higher than the standard recommended by the EU (2008) $\left(0.05\right.$ mg.kg $\left.{ }^{-1}\right)$, and lower than those reported in cauliflower samples from China $\left(0.018 \mathrm{mg} . \mathrm{kg}^{-1}\right)$ (Sinha et al., 2012) and India (2.85 mg. $\left.\mathrm{kg}^{-1}\right)$ (Mandal and Singh, 2010; Sinha et al., 2012).

Similar studies carried out in Nigeria (Adeyeye and Osibanjo, 1999), in Ghana (Ntow, 2001), and in Gambia (Manirakiza et al., 2003; Williamson, 2008) revealed contaminations of tubers, fruit and vegetables by various residues of pesticides; all higher than the LMR enacted by WHO (2004) and the European Union (EU, 2008).

A total of seven active ingredients (permethrin, tetramethrin, cypermethrin, $\lambda$ cyhalothrin, deltamethrin, heptachlor, and lindane) were detected in the babenda leaf sauce.

The results of this study are consistent with those reported by FAO (2004) with reference to the Codex Alimentarius (2010) who adopted these definitions and classifications of foods for the purpose of pesticide residue controls. The committee recorded a 50\% decrease in organochlorine residues in carrots and a $10-25 \%$ removal of pyrethroids in cabbage after cooking. Other existing heat treatment results suggest that bleaching of vegetables results in a 20-40\% decrease in organochlorine insecticides in spinach compared to $30-80 \%$ pyrethroids (FAO / WHO, 2004)

DGAL (2000) reported that identical meals or "duplicate meals" collected from 25 sites and 5 regions were containing six residues that are at least 1-times highe than the limit of quantification; and 4 of the residues have never been quantified. The analysis showed that the contamination is not significant. The results of this study are in line with those reported by the EFSA (2007), who found out that over $97 \%$ of the food tested contained pesticide residues within the allowed limits.

This constitutes a true problem of public health because the vegetables produced in these small farms located near the urban centres occupy a significant place in the daily food of the cities populations.

\section{CONCLUSION}

The majority of vegetables tested present contamination by heavy metals and pesticides that are alarming. The pesticides and heavy metals contents present in vegetables in the various markets of Ouagadougou town were tested. The majority of the samples showed that the contents of pesticides are relatively higher than the contents of heavy metals; probably because of the excessive use of pesticide chemicals by industries, mining activities and animal husbandries. The risk of contamination of the food chain by the consumption of the vegetables sold on the markets of Ouagadougou town are not negligible. This contamination could be the cause of many diseases suffered by the consumers. It can also cause damage in agricultural production like breeding.

The results obtained in this study are significant in the sense that it shows that human health is directly affected by the consumption of the vegetables. The monitoring of pesticides and heavy metals contents in the vegetables intended for the preparation of "babenda" sauce must be continued; because this sauce is highly consumed during great ceremonies (marriages, baptisms, university canteens and households) in Burkina Faso.

Acknowledgments: This work was supported by the Islamic Bank of Development. The authors highly recognize and express their gratitude for the support by the LNSP and the ONEA who provided the technical platform for the analyses.

\section{REFERENCES}

ADEYEYE, A., OSIBANJO, O. 1999. Residues of organochlorine pesticides in fruits vegetables and tubers from Nigerian market. Science of the Total Environment, 231, 227-233. https://doi.org/10.1016/s0048-9697(99)00067-4

ADU, A.A., ADERINOLA, O.J., KUSEMIJU, V. 2014. Assessment of trace metal levels in commonly edible vegetables from selected markets in Lagos state, Nigeria. Current World Environment, 9, 3, 789-796 https://doi.org/10.12944/cwe.9.3.28.

ADU, A.A., ADERINOLA, O.J., KUSEMIJU V. 2012. Heavy metals concentration in Garden lettuce (Lactuca Sativa L.) grown along Badagry expressway, Lagos, Transnat. Journal of Science and Technology, 7, 2, 15-130 https://doi.org/10.12944/cwe.9.3.28

AHMAD, J.U., GONI, M.A. 2010. Heavy metal contamination in water, soil, and vegetables of the industrial areas in Dhaka, Bangladesh. Environmental Monitoring and Assessment, 166, 347-357. https://doi.org/10.1007/s10661-0091006-6

AHOUANGNINOU, C., FAYOMI, B.E., MARTIN, T. 2011. Evaluation of the medical and environmental risks of the plant health practices of the marketgardening producers in the rural district of Tori-Bossito (South-Benign). Cahiers Agricultures, 20, 3, 216-222. https://doi.org/10.4236/iep.2012.33030

ALINA, M., AZRINA, A., MOHD YUNUS, A.S., MOHD ZAKIUDDIN MOHD IZUAN EFFENDI S., MUHAMMAD RIZAL H., MOHD IZUAN
EFFENDI, R. H., MUHAMMAD RIZAL, R. 2012. Heavy metals (mercury, arsenic, cadmium, plumbum) in selected marine fish and shellfish along the Straits of Malacca. International Food Research Journal, 19, 1, 135-140. https://doi.org/10.1155/2013/284329

AL-RMALLI, S.W., JENKINS, R.O., HARIS, P.I. 2012. Dietary intake of Cd from Bangladesh foods. Journal of Food Science, 77, 1, 26-33.

ANASTASSIADES M. 2005. Quechers: A mini-multiresidue method for the analysis of pesticide residues in low-fat products, Chemisches und Veterinaruntersuchung Sant Stuttgart, 12p. https://doi.org/10.1111/j.1750 3841.2011.02467.x

ASSOGBA-KOMLAN, F., ANIHOUVI, P., ACHIGAN, E., SIKIROU, R., BOKO, A., ADJE, C., AHLE, V., VODOUHE, R., ASSA A. 2007. Practical farming and content of nutritional anti elements (nitrates and pesticides) of Solanum macrocarpum in the south of the Benign one. African Journal of Food Agriculture Nutrition and Development, 7, 4, 1-21.

AWOFOLU, O.R. 2005. A survey of trace metals in vegetation, soil and lower animals along some selected major roads in metropolitan city of Lagos, Environmental Monitoring and Assessment, 105, 431-447. https://doi.org/10.1007/s10661-005-4440-0

BAISE, D., PAQUEREAU, H., 1997. Total trace elements content in the agricultural soils of Seine-et-Marne. Soil Survey and Management. Science du Sol - I.N.R.A. - Orléans. - Domaine de Limère - 45160 Ardon, 4(2), 77-94.

BEMPAH, K. C., BUAH-KWOFIE, A., ENIMIL, E., BLEWU, B. ANDAGYEIMARTEY, G. 2012. Residues of organochlorine pesticides in vegetables marketed in Greater Accra Region of Ghana. Food Control, 25, 537-542. https://doi.org/10.1016/j.foodcont.2011.11.035

CHOWDHURY, A. Z, FAKHRUDDIN A.N.M., ISLAM N, MONIRUZZAMAN M, GAN S.H., ALAM K. 2013. Detection of the residues of nineteen pesticides in fresh vegetable samples using gas chromatography, mass spectrometry. Food Control, JFCO3271_proof, p 1-9. https://doi.org/10.1016/j.foodcont.2013.05.006

MATTHYS, B., ADIKO, A.F., CISSÉ, G. 2006. Le réseau social des maraîchers à abidjan agit sur la perception des préoccupations et des risques sanitaires liés à l'eau. Electronic Review In Sciences of the environment, Hors-Série 3 https://doi.org/10.4000/vertigo.1857

CODEX ALIMENTARUIS. 2010. Residues of pesticides in the food (maximum limits of residues). In ED FAO. 87p.

COLY, A. 2000. Seek and proportioning of the organochlorinated pesticides in the mother's milk on the level of the area of Dakar. Thesis of doctorate in pharmacy, postgraduate thesis in Chemistry-Physics UCAD, Dakar, 236p.

CONGO, K. 2013. Risques sanitaires associes à l'utilisation de pesticides autour de petites retenues : cas du barrage de loumbila. In Mémoire master 2iE. p. 68.

DAO, L., MORRISON, L., ZHANG, C. 2010. Spatial variation of urban soil geochemistry in a roadside sports ground in Galway, Ireland. Science of the Total Environment, 408, 1076 - 1084. https://doi.org/10.1016/j.scitotenv.2009.11.022 DEMBELE, A., OUMAROU, B., TRAORE, S.K., M AMADOU, K., COULIBALY, D.T., ABBA, T. 2008. The chemical control of the pests in the truck farming and the quality of vegetables in African urban cities: the health hazards and security of consumers. European Journal of Scientific Research, 20 836-843. https://doi.org/10.5772/18368

DIOP, A. 2013. Diagnostic des pratiques d'utilisation et quantication des pesticides dans la zone des Niayes de Dakar (Sénégal). In Thèse de doctorat Chimie analytique. p. 241.

DOUAY, F., STERCKEMAN, T. 2002. Contents $\mathrm{Pb}, \mathrm{Cd}$ and $\mathrm{Zn}$ in the plants cultivated in the neighbourhoods of iron-foundries. In D. Baise and M. Tercé The metal elements traces in the grounds. Functional and space approaches, INRA Editions. Paris, 505-521. https://doi.org/10.1016/s0269-7491(99)00165-7

DOUMBIA, M., KAWDJIO, K. E. 2009. Practical of use and management of the pesticides by the market-gardeners in Côte d'Ivoire: Case of the town of Abidjan and two of its suburbs (Dabou and Anyama). Newspaper of Applied Biosciences, $18,992-1002$.

EC. 2002. Commission Directive 2002/63/EC of 11 July 2002 establishing community methods of sampling for the official control of pesticide residues in and on products of plant and animal origin and repealing directive 79/700/EEC Official Journal of European Communities, 187, 30-43.

EFSA. 2007. Opinion of the Scientific Panel on Plant protection products and their Residues on acute dietary intake assessment of pesticide residues in fruit and vegetables. EFSA Journal, 538, 1-88. https://doi.org/10.2903/j.efsa.2007.538 E U (Europeenne Union). 2008. Maximum limits applicable to the residues of pesticides present in or on the foodstuffs and feeding stuffs of vegetable origin. Official Journal of the European Union, 67-71.

E U (Europeenne Union). 2010. Maximum limits applicable to the residues of pesticides present in or on the foodstuffs and feeding stuffs of vegetable origin, Official Journal of the European Union, 67-71.

FAO/WHO, CODEX ALIMENTARIUS COMMISSION. 2001. Food Additives and Contaminants. Joint FAO/WHO Food Standards programme, ALINORM 01/12A, 1-289.

FAO/WHO. 2004. List of maximum levels recommended for contaminants by the Joint FAO/WHO Codex Alimentarius Commission. 
FAO/WHO. 2011. Joint FAO/WHO Food Standards Programme Codex Committee on Contaminants in Foods, Food CF/5 INF/1. Fifth Session. The Hague, the

Netherlands.

ftp://ftp.fao.org/codex/meetings/CCCF/cccf5/cf05_INF.pdf

FARAG, R.S., ABDEL-LATIF, M.S., ABD EL-GAWAD, A.E., DOGHEIM, S.M. 2011. Monitoring of pesticide residues in some Egyptian herbs, fruits and vegetables. International Food Research Journal, 18, 659-665. https://doi.org/10.1080/02652030210157655

GROBELAK, A., NAPORA, A. 2015. The chemophytostabilisation process of heavy metal polluted soil. PLoS One, 10, 6, 129-538.

GUPTA, N., KHAN, D.K., SANTRA, S.C. 2008. An assessment of heavy metal contamination in vegetables grown in wastewater-irrigated areas of Titagarh, West Bengal, India. Bulletin of Environmental Contamination and Toxicology, 800, 115-118. https://doi.org/10.1007/s00128-007-9327-z

IMPERATO, M., ADAMO, P., NAIMO, D., ARIENZO, M., STANZIONE, D., VIOLANTE, P. 2003. Spatial distribution of heavy metals in urban soils of Naples city (Italy). Environmental Pollution, 124, 247-256. https://doi.org/10.1016/s0269-7491(02)00478-5

ISLAM, M., SHAMSAD, S. 2009. Assessment of irrigationwater quality of Bogra district in Bangladesh. Bangladesh Journal of Agricultural Research, 34 4, 507-608.

ISLAM, M.S., AHMED, M.K., HABIBULLAH-AL-MAMUN, M. 2015. Determination of heavy metals in fish and vegetables in Bangladesh and health implications. Human and Ecological Risk Assessement, 21, 4, 986-1006. https://doi.org/10.3329/bjar.v34i4.5836

ROBERT M AND JUSTE C. 1999. Impact of the activities lombricians on (1) the quality of cut-off waters and in particular their load in metal elements traces $(\mathrm{Cu}, \mathrm{Cd}, \mathrm{Pb}$ and $\mathrm{Zn})$ and $(2)$ of the redistribution of these elements within the particular microsites of the ground, CRIN, Paris, 495.

KALONDA, D. M., TSHIKONGO, A. K., KODONDI KULE KOTO, F. KASONGO BUSAMBWA,C., BWALYA, Y. K., MUSOLA CANSA H., KAHAMBWE, J.L.,TAMBWE, Z., KALALA L., LONGANGA OTSHUDI A. 2015. Profile of the heavy metals contained in the food plants usually consumed in some mining zones of the province of Katanga. Journal of Applied Biosciences, 96, 9049-9054.

KANDA, M., WALA, K., BATAWILA, K., DJANEYE-BOUNDJOU, G., AHANCHEDE, A., AKPAGANA, K. 2009. Le maraîchage périurbain à Lomé: pratiques culturales, risques sanitaires et dynamiques spatiales. Cahiers Agricultures, 18, 356-63. https://doi.org/10.4000/vertigo.13456

KANDA, M., DJANEYE-BOUNDJOU, G., WALA, K., GNANDI, K. BATAWILA, K., SANNI, A., AKPAGANA, K. 2013. Assessment of pesticide residues and trace element contamination in market gardens of Togo. African Journal of Environment Science and Technology, 6, 380-390.

KOFFI-NEVRY, R., ASSI-CLAIR, B.J., ASSEMAND, E.F., AFFOU, S.W., KOUSSEMON, M. 2012. Origin of the witnesses of fecal contamination of the water of watering of the lettuce (Lactuca sativa) cultivated in the zone périurbaine of Abidjan. Journal of Applied Biosciences, 52, 3669-3675.

KOUMOLOU, L., EDORH, A.P., AGBANDJI, L., HOUNKPATIN, S. A. ELEGBEDE, B. 2012. Threat of the health quality of garden produces linked to pollution by toxic metals on some gardening sites of Benin. American Journal of Environ. Sciences, 8, 3, 248-52. https://doi.org/10.3844/ajessp.2012.248.252

LATIF C. Y., SHERAZI S. T H, BHANGER M. I. 2011. Assessment of pesticide residues in commonly used vegetables in Hyderabad, Pakistan. Ecotoxicology $\begin{array}{llll}\text { and Environmental } & \text { Safety, } & 74, & \end{array}$ https://doi.org/10.1016/j.ecoenv.2011.07.030

LI, X., POON, C.S., LIU, P. S. 2001. Heavy metal contamination of urban soils and street dusts in Hong Kong. Applied Geochemistry, 16, 1361 - 1368 https://doi.org/10.1016/s0883-2927(01)00045-2

LOCK, K., POMERLEAU, J., CAUSER, L., ALTMANN, D.R., MCKEE, M 2005.The global burden of disease attributable to low consumption of fruit and vegetables: implications for the global strategy on diet. Bulletin of the World Health Organization; 83: 100-108.MANDAL, K., SINGH, B. 2010.Magnitude and frequency of pesticide residues in farmgate samples of cauliflower in Punjab, India.Bulletin of Environmental Contamination and Toxicology, 85 (4), 423-426. https://doi.org/10.1007/s00128-010-0107-9

MANIRAKIZA, P., AKINBAMIJO, O., COVACI, A., PITONZO, R. AND SCHEPENS, P. 2003. Assessment of organochlorine pesticide residues in West African City Farms: Banjul and Dakar case study. Archives of Environmental Contamination and Toxicology, 44, 171-179. https://doi.org/10.1007/s00244002-2006-5

MENCH, M., BAIZE, D. 2004. Contamination of the grounds and our food of vegetable origin by the elements in traces. Measurements to reduce the exposure, INRA Environmental Mail, 52 (52), p.31-56.

MOURATO, M.P., MOREIRA, I.N., LEITÃO, I., PINTO, F.R., SALES, J.R AND MARTINS, L. L. 2015. Effect of Heavy Metals in Plants of the Genus Brassica. Internal Journal of Molecular Sciences, 16 (8), 17975-17998. https://doi.org/10.3390/ijms160817975

MPUNDU, M. M. M., USENI, S. Y., NTUMBA, N. F., MUYAMBO, M. E., KAPALANGA, K. P., MWANSA, M., ILUNGA, K. L., NYEMBO, K. 2013. Évaluation des teneurs en éléments traces métalliques dans les légumes feuilles vendus dans les différents marchés de la zone minière de Lubumbashi. Journal Applied Biosciences, 66, 5106- 5113. https://doi.org/10.4314/jab.v66i0.95008

MUHAMMAD, F., FAROOQ, A., UMAR, R. 2008. Appraisal of heavy metal contents in different vegetables grown in the vicinity of an industrial area. Pakistan Journal of Botany, 5 (40), 2099-2106. https://doi.org/10.1155/2013/194765

NDLOVU, J., AFOLAYAN, A.J. 2008. Nutritional analysis of the South African wild vegetable Corchorus olitorius L. Asian Journal of Plant Science; 7: 615-8. SHAHEEN, N., IRFAN, N.M., KHAN, I. N., ISLAM, S., KAWSER, A. 2016. Presence of heavy metals in fruits and vegetables: Health risk implications in Bangladesh. Chemosphere, 152,

https://doi.org/10.1016/j.chemosphere.2016.02.060

NOUBISSIÉ, E. 2015. Spéciation des composés organométalliques $(\mathrm{Hg}, \mathrm{Sn}, \mathrm{Pb})$ dans les sols des cultures maraîchères et dans trois espèces de plantes cultivées àNgaoundéré (Cameroun). Thèse de Doctorat en Chimie Analytique et Environnement. 255p.

NTOW, W. J., GIJZEN, H. J., KELDERMAN, P. AND DRECHSEL, P. 2001. Organochlorine pesticides in water, sediment, crops and human fluids in a farming community in Ghana. Archive of Environmental Contamination Toxicology, 40, 557-563. https://doi.org/10.1007/s002440010210

PARK, J., KIM, J.-Y., KIM, K.-W. 2012. Phytoremediation of soil contaminated with heavy metals using Brassica napus. Geosystem Engineering, 15, 9-17. https://doi.org/10.1080/12269328.2012.674428

QOZOWICKA, B., JANKOWSKA, M., KACZYNSKI, P. 2012. Pesticide residues in Brassica vegetables and exposure assessment of consumers. Food Control, 561-575. https://doi.org/10.1016/j.foodcont.2011.11.017

QUI, X.X., HUANG, D.F., CAI, S.X., CHEN, F., REN, Z.G., CAI, Y. 2000 Investigation on vegetables pollution and pollution sources and its control in Fuzhou, Fujian Province. Fujian Journal of Agricultural. Science, 15, 16-21.

QUINTERO, A., CASELlES M. J., ETTIENE, G., COLMENARES, N G., RAMÃREZ, T., MEDINA, D. 2008. Monitoring of organophosphorus agricultural pesticide residues in vegetables of area in Venezuela. Bulletin of Environmental Contamination and Toxicology, 81, 4, 393-396. https://doi.org/10.1007/s00128-008-9511-9

RAHMAN, M.M., ASADUZZAMAN, M., NAIDU, R. 2013. Consumption of As and other elements from vegetables and drinking water from an Ascontaminated area of Bangladesh. Journal of Hazard Materials, 262, 1056-1063. https://doi.org/10.1016/j.jhazmat.2012.06.045

NGOM, S., MANGA, A., DIOP, M., THIAM, M.B., CISSE, J.R. I. AND TRAORE, S. 2013. Study of the evolution of the residues of pesticides in the horticultural products of great consumption in Senegal. Review of Ivoire Science and Technology, 21-22, 31-44.

SEPA. 2005. The Limits of Pollutants in Food. State Environmental Protection Administration, China. China's Maximum Levels for Contaminants in Foods 2762-2005.

SINHA, S.N., RAO, M., VASUDEV, K. 2012.Distribution of pesticides in different commonly used vegetables from hyderabad, India.Food Research International, 45, 1, 161-169. https://doi.org/10.1016/j.foodres.2011.09.028 SON, D., SOMDA, I., LEGREVE A., SCHIFFERS, B. 2017. Practical plant health of the tomato producers of Burkina Faso and health risks and the environment. Book Agriculture, 26, 25005. https://doi.org/10.1051/cagri/2017010 SORO, L.C, OCHO-ANIN, A., KOUAMÉ, A., KOUAMÉ, C. 2012. Evaluation de la composition nutritionnelle des légumes feuilles. Journal of Applied Biosciences; 51: 3567 - 3573. STEVENS, T J., KILMER, R. L. 2009.With descriptive and comparative analysis of pesticide residues found in Florida tomatoes and strawberries. IFAS/Ext BUL331, University of Florida, Journal of Water Re source and Protection , 4, 107-114 http://dx.doi.org/10.4236/jwarp.2012.43013

REHMAN, Z.U., KHAN, S., BRUSSEAU, M. L., SHAH, M.T. 2016. Lead and cadmium contamination and exposure risk assessment via consumption of vegetables grown in agricultural soils of five-selected regions of Pakistan. Chemosphere 68:1589-1596. doi: 10.1016/j.chemosphere.2016.11.152. https://doi.org/10.1016/j.chemosphere.2016.11.152

TANO, B.F., ABO, K., DEMBELE, A., FONDIO, L. 2011. Systèmes de production et pratiques à risque en agriculture urbaine: Cas du maraîchage dans la ville de Yamoussoukro en Côte d'Ivoire. International Newspaper of Biological and Chemical Sciences, 5, 2317-2329. https://doi.org/10.4314/ijbcs.v5i6.12

TARNAGDA, B., TANKOANO, A., TAPSOBA, F., SOURABE, P.B. ABDOUllaH, H. O., DJBRINE, A.O., DRABO, K.M., TRAORE, Y., SAVADOGO, A. 2017. Evaluation des pratiques agricoles des légumes feuilles: le cas des utilisations des pesticides et des intrants chimiques sur les sites maraichers de Ouagadougou, BURKINA FASO. Journal of Applied Biosciences, 117, 11658-11668. https://doi.org/10.4314/jab.v117i1.3

TOURE, N.K.P., K., YOBOUE, K.E., YAO-KOUAME, A. 2015. Evaluation of the heavy metals traces, pesticides and plasticizers in the products maraichers (gombo, corete potagere, epinard and aubergine) in lavallee of the nieki, southeast of the Côte.d'ivoire. European Scientific Newspaper, 11, 33, 14. 
UBALUA, A.O., CHIJIOKE, U.C., EZERONYE, O.U. 2007. Determination and assessment of heavy metal content in fish and shellfish in aba river, abia state, nigeria. kmitl Science of Technology Journal, 7, 1, 8.

WILLIAMSON, S., BALL, A., PRETTY, J. 2008. Trends in pesticide use and drivers for safer pest management in four African countries. Crop Protection Journal, 27, 1327-1334.WOLFF, M. 2003. Contribution of the geometrical analysis of the data for modeling of the activity.In SPERANDIO J.C. and WOILFF, (Eds).Formalisms of modeling for the analysis of work and ergonomics, ParisUniversity presses of France, 195 - 227 https://doi.org/10.1016/i.cropro.2008.04.006

WOLFF, M., TO VISSER, W. 2005. Methods and tools for analysis of the entries of charge:A contribution to the analysis of the model of the interlocutor in the description of routes2, $99-118$.

WONG, J.W., LI G.X., WONG, M. 1996. The growth of Brassica Chinensis in heavy metal contaminated sludge compost from Hong Kong. Bioresource Technology Journal, 58, 209-313.

WHO. 2004. Guidelines for food and drink water quality, $460 \mathrm{p}$.

YAO, B.L., KPAN KPAN, G.K., MESSOUM, F.G., DEMBELE, A., TRAORE,

K. S. 2016. Evaluation of the plant health risk related to the consumption of the lettuce (lactuca sativa) cultivated in the commune of Port-Bouët (Abidjan). Review of Marine Science Agricultural and Veterinary, 4, 3, 23-30. 